\title{
Bakhtin and Cohen: The First Stages in Building the Philosophical System
}

\author{
Ilya Dvorkin $\bowtie$ \\ Hebrew University of Jerusalem, \\ Mt. Scopus, Jerusalem, 9190501, Israel \\ \idvorkin@mail.ru
}

\begin{abstract}
Abstact. Although it is generally known that M.M. Bakhtin viewed himself as primarily a philosopher and not a philologist, the overwhelming majority of studies of his work belong to literary criticism. The purpose of this article, relying on the oral testimony of Bakhtin himself and his philosophical texts written in the Nevel-Vitebsk period (1919-1924), is to restore the origin of his philosophical sources and the content of his philosophical ideas of this period. The main idea is the concept of moral philosophy as a philosophical system, whose main subject is participative thinking and an answerable act as an event of being. One of the most important sources of these ideas was probably the philosophy of Neo-Kantianism represented by the teachings of $\mathrm{H}$. Cohen. The article provides four examples of Bakhtin's continuity in relation to the Marburg philosopher - the idea of an answerable act concerning another person as the source of a human's self-consciousness and personal integrity, the idea of a correlative relationship between a person and his neighbor as an expression of a caring participatory being, the idea of distinguishing a moral attitude from an ethical-legal one and the idea of the philosophical system, whose subject is the process of interpersonal relations. In this case, the system consists not only in the integrity of the object but also in its openness. Revealing the continuity of Bakhtin's philosophical ideas regarding Cohen leads to a better understanding of these ideas and Bakhtin's originality of their development. It is also fruitful to compare the perception of Cohen's ideas by Bakhtin and their reception by another philosopher of dialogue, F. Rosenzweig.
\end{abstract}

Keywords: Bakhtin, Cohen, Rosenzweig, participative thinking, act, answerability, correlation, event of Being, system, morality, ethics, philosophy of dialogue

Article history:

The article was submitted on 14.05.2021

The article was accepted on 03.08.2021

(C) Dvorkin I., 2021

This work is licensed under a Creative Commons Attribution 4.0 International License https://creativecommons.org/licenses/by/4.0/ 
For citation: Dvorkin I. Bakhtin and Cohen: The First Stages in Building the Philosophical System. RUDN Journal of Philosophy. 2021;25(3):436-456. DOI: 10.22363/2313-23022021-25-3-436-456

\section{Introduction. Bakhtin's Philosophical Sources: Testimonies}

During the first visit of the then young Moscow literary scholars to Saransk in June 1961, Bakhtin started his conversation with his admirers by declaring: "I am not a literary scholar, but a philosopher" ${ }^{1}$. He has asserted many times under different circumstances that he is a philosopher [1. P. 476, 478 $]^{2}$. However, to understand any philosophical doctrine, it is necessary to discover its intellectual context, with whom the author in question is arguing, on whom he is describing, what questions he is asking. In the case of Bakhtin, this is especially important. From the time when he could freely express his philosophical beliefs, only individual passages, published already after his death, remain ${ }^{3}$.

One of the most vivid testimonies of Bakhtin's philosophical continuity is contained in two articles by S.G. Bocharov, About One Conversation and its Context [1. P. 472-502], and Event of Being [1. P. 503-520]. It is difficult to overestimate the importance of these memoirs since the author manages to convey Bakhtin's lively voice. In the first article, Bocharov writes:

Once when asked about his attitude to Russian religious philosophy, he answered (January 25, 1971): "I was fond of the Marburg school - it says it all." From remarks in conversations, we could conclude that he somehow did not appreciate the new Russian philosophy very much. It passed for him more under the category of "free thinking" than philosophy in the proper sense. He was inclined to understand philosophy as a "strict science" [1. P. 478].

As it happens, I learned about this conversation from Bocharov himself before I read the article. During our meeting in May 2005, Bocharov told me that when he was with Bakhtin at the nursing home at Grivno Station, an important conversation about Bakhtin's philosophical roots took place. The conversation, as Bocharov said, involved the French Slavist Annie Epelboin. In response to her question about Bakhtin's philosophical roots, he denied Russian philosophy's influence and said: "I am a follower of Hermann Cohen. That says it all!" I then asked Bocharov if he had published this conversation with Bakhtin. "Yes, I published it in NLO [The New

\footnotetext{
${ }^{1}$ S.G. Bocharov, V.V. Kozhinov, and G.D. Gachev participated in this trip, which determined many future events. [1. C. 482].

${ }^{2} \mathrm{D}$ : Were you more of a philosopher than a philologist? // B: A philosopher. I am still a philosopher. I am a philosopher. I am a thinker. [2. P. 41-42].

${ }^{3}$ In this paper we rely on the first volume of the academic collection of M.M. Bakhtin's works [3]. The citation of his early works discussed in this article is based on English translations - "Art and Answerability" [4. P. 1-3], "Toward a Philosophy of the Act" [5. P. 1-100], "Author and Hero in Aesthetic Activity" [4. P. 4-256], and the article "The Problem of Content, Material, and Form in Verbal Art" [4. P. 257-325]. This article, as we know, was prepared in 1924, but was left unpublished until 1975.
} 
Literary Observer] in 1993." - Bocharov replied ${ }^{4}$, — "but not in full. It should be published in more detail!"

The first foreigner to visit Bakhtin there was Annie Epelboin, a Slavist from

Paris (we came with her and Leo Shubin [1. P. 473].

Why does Bocharov suddenly talk about Epelboin here but is silent about her when Bakhtin answers her question? This seems to be a problem for the psychoanalyst. Bocharov, of course, remembers the conversation perfectly well, as can be seen in his retelling of it in June 2005. As a faithful narrator, Bocharov could not fail to mention the French Slavist at all, but some reason led him to write about her elsewhere in the article out of context.

The second strange circumstance is that, according to the text of the article, Bakhtin answers about Marburg Neo-Kantianism to "the question about the attitude to Russian religious philosophy." Finally, it is not entirely clear what Bocharov meant by "one conversation." Its importance for him is pretty apparent from the context. However, the first article refers to "one conversation" as a dialogue that took place in June 1970 and concerned Bakhtin's relationship to his book on Dostoevsky:

This conversation took place on June 9, 1970, in the nursing home at the Grivno station of the Kursk railway, where M.M. and Elena Aleksandrovna had moved in three weeks before" [1. P. 472].

Epelboin did not participate in this conversation, although Bocharov talks about her here. The conversation about philosophy in which the French Slavist participated occurred on January 25, 1971. We can also note that during the 2005 conversation, Bocharov says on behalf of Bakhtin: "I am a follower of Hermann Cohen. This says it all", while in the article, he says more vaguely, "I was fond of the Marburg school - it says it all." It is clear that in these words, there is a shift of emphasis.

In the article Event of Being, Bocharov also recounts this conversation. Here Epelboin is directly mentioned, but also not as the initiator of the conversation, but incidentally, as one of the participants:

In one conversation (January 25, 1971), I asked M.M. whether and to what extent a thinker is responsible for using his ideas. It was about the fashion that had emerged not only for Nietzsche but also for Kierkegaard. Kierkegaard, he said, would not be vulgarized like Nietzsche, and not only for external reasons but because of the very quality of thought. (Moreover, Hermann Cohen, he added, would never become fashionable; he is still very little known in France: Annie Epelboin, a Slavist from Paris, took part in the conversation [1. P. 515].

In this case, "one conversation" is already referred to as the conversation of January 25, 1971. Annie Epelboin is mentioned in connection with the fact that Cohen is little known in France. All these oddities forced me to begin a search, as I

\footnotetext{
${ }^{4}$ This article was first published in The New Literary Observer, 1993, № 2.
} 
decided, for the most crucial participant in this conversation, Annie Epelboin herself. Although it took many years, the result fully rewarded the effort. Annie Epelboin turned out to be a professor at the Sorbonne, an expert on Andrei Platonov. I found her in 2015 but did not have the opportunity to record her detailed account of her meeting with Bakhtin until November 24, 2020.

In the context of this article, I cannot quote in full her fascinating story ${ }^{5}$. In describing this meeting, Epelboin says that when Bocharov and Shubin took her by train to the senior home to meet Bakhtin, she was a little skeptical about the visit, since the perception of Bakhtin as a saint, as Bocharov and Shubin saw him, was alien to her. The day before, she had discussed with her philosopher friend M. Mamardashvili Nietzsche's book "Twilight of the Idols, or, How to Philosophize with a Hammer" and her veneration of Bakhtin as a "saint" evoked a certain degree of sarcasm. Below I cite the main excerpt from our conversation with Annie Epelboin about her visit to Bakhtin:

AE. I was sitting against the wall. Sergey Bocharov and Lev Shubin were sitting next to him. A conversation began. They were telling him about publishing his texts in different places and maybe in different languages (I do not remember this). I had the impression of a pilgrimage: how he was praised and approved. He did not say anything. He listened, rather sluggishly, it seemed to me, and I got bored. I thought he was bored, too. I was not paying attention to these conversations anymore. Suddenly, I hear, "What does our French guest think?" I woke up...

I was frightened that I was thinking impolitely about something else. And I said that I was doing Platonov, but I don't think he was reading him generally at the time or was not interested. Suddenly I said: "Have you read Nietzsche's "How to Philosophize with a Hamme" because that's what I wanted. And suddenly, he was so awake and lively and said with a smile: "Of course! It's a beautiful text! And in fact, I've read Nietzsche." And I said I'd read it. And we started talking about philosophy. And I said to him: "I have the impression that your philosophical culture coincides with mine. He said: "Yes, of course! Because I'm familiar with German culture through my friend ..." Here in I cannot read my notebooks. I think I wrote down the name of his friend who was studying at Marburg. And he said he knew Marburg quite directly, that school, the university. I cannot tell you about the details right now. But I wrote down the last name!

ID. The German philosopher or his friend?

AE. That philosopher! His friend who used to study at Marburg and told him about Hermann Cohen. I remember that I wrote it down. Cohen or Kogan, I do not know. So, it turned out that we explained to each other that we had a culture not in common, of course, but close, that he was familiar with this German school of philosophy and culture in general.

\footnotetext{
5 The full text of the interview is published in the issue of the journal Judaica Petropolitana, devoted to the philosophy of dialogue (see [6]).
} 
I am quoting Annie Epelboin's speech verbatim since she is an entirely neutral witness. She is not familiar with the philosophy of Hermann Cohen and remembers his name because she has it "written down." Nevertheless, Epelboin informs us that Bakhtin is related to Cohen through his friend who "studied with him at Marburg." We are referring, of course, to Matvei Kagan. Epelboin does not remember his name, but he recalls being the link between Bakhtin and German philosophy. We know, of course, that Bakhtin read Kant and Cohen in German long before he met Kagan, but Epelboin's testimony conveys Bakhtin's mental attitude toward philosophy. At the age of 76 in a nursing home, for him, philosophy is Hermann Cohen and Matvei Kagan. From Epelboin's account, we understand Bocharov's bewilderment and his problematic attitude toward this "one conversation." This is also evident from the end of the interview:

\begin{abstract}
AE. So that was our meeting in this nursing home. We drank tea. I thought it was delightful, for me and maybe for him. Then we said goodbye, got on the train, and I remember that they, my friends Bocharov and Shubin, were silent at first. And suddenly, Sergei Bocharov turned to me and said: "And how did you manage to get him to talk (in Russian "razgovorit")?" It was strange to me that I managed to get him to talk. I remember this phrase, especially since the word " razgovorit " was not yet familiar to me. I realized that it was strange for them that I started talking to him [Bakhtin] that way. And it was true, the only moment when he became a living person, very, apparently, pleased with the conversation. Here's what I can tell you.
\end{abstract}

Now we can reconstruct this "one conversation," or rather the part of it that is so important to us. Epelboin and Bakhtin were talking about philosophy. Apparently, the French slavist did not ask Bakhtin directly about the sources of his philosophy. That topic was of interest to Bocharov. Bakhtin spoke about Russian philosophy in the conversation context, he rejected it as his primary source, but this was not an important topic of conversation. Bocharov thought Bakhtin's attitude to "free thinking" was dismissive. However, Epelboin did not hear anything of the sort. In general, an evaluative attitude toward philosophy was more characteristic of Bocharov than of Bakhtin and Epelboin. Bakhtin speaks of his commitment to Cohen's philosophy. Here Epelboin confirmed the oral version of Bocharov's account rather than the written one, but as she noted, Bakhtin spoke more gently. He did so of Cohen and Kagan, Nietzsche and Kierkegaard, but not as a "fashion," but as a philosophy he loved. However, the most important lesson we can draw from this "one conversation" is that Bakhtin appeared closer in culture to an unfamiliar young Frenchwoman than to his admirers, the Moscow literary critics ${ }^{6}$.

I want to cite one more testimony, which everyone knows, but in this case, it nicely completes the picture of Bakhtin's attitude to philosophy. In his conversations with V. Duvakin, Bakhtin repeatedly mentions the influence of

\footnotetext{
${ }^{6}$ This is not, of course, about Bakhtin's ingratitude to his circle of saviors from oblivion. Bakhtin, of course, was well aware and very appreciative of their efforts. It is about the cultural distance that formed between Bakhtin and the Soviet intellectuals of the 1960s and 1970s.
} 
Hermann Cohen on him. Although Duvakin had absolutely no idea who Bakhtin was talking about and was not very interested in it, Bakhtin speaks about an essential topic for himself at the first opportunity. The first time this happens is when he talks about his studies in the Odessa gymnasium, where the teacher Nikolay Nikolaevich Lange is "a fine professor" but has not read Hermann Cohen's book Kant's Theory of Experience [2. P. 35]. Duvakin heard about Cohen only from Boris Pasternak's Safe Conduct. In this connection, Bakhtin recalls Andrei Bely mentioning Cohen.

D: And I also know it [Cohen's name] only by hearsay, in connection with Pasternak.

B: That's right, that's right. Bely also has this quote: The Marburg philosopher Cohen, // Creator of dry methodologies... Well, this is, of course, an absolutely incorrect description: "Creator of dry methodologies." He was a great philosopher who had a tremendous influence, a tremendous influence on me. Well, we will talk to you later, we will come to this [2. P. 35-36].

Duvakin is not interested in Cohen but still asks about him out of politeness, to which Bakhtin gives a detailed account:

D: Mikhail Mikhailovich, so the heyday of the Marburg School was the late 1990s?

B: Yes, yes. The first works were published back in the 1980s. Hermann

Cohen's. And then it was... It was his system of philosophy in three volumes. [2. P. 40].

The detail of Bakhtin's story testifies to his undisguised interest in this topic. Duvakin, sensing this, asks who was with him at the time. To which Bakhtin states:

B: Next to me was a man whom I met much later and who became one of my closest friends. He himself had studied directly in Germany, under Hermann Cohen. He has long since passed away, but his daughter comes to visit me.

D: And who is that?

B: That's Matvei Isayevich Kagan [2. P. 41].

This response reflects well on the psychological background of the conversation. Duvakin consistently interrogates Bakhtin about his biography and is in the time of his respondent's schooling in the Odessa Gymnasium in 1912. Bakhtin speaks of Matvei Kagan, who was the interlocutor of his life. Of course, Bakhtin and Kagan met many years later, but for Bakhtin, this is unimportant. As in the case of Annie Epelboin, he is talking about something more significant than some moment in life. The same picture emerges from Bakhtin's correspondence with Kagan and especially from Kagan's daughter's biographical article People not of our Time [7].

Does this mean that Bakhtin was a Neo-Kantian or Neo-Cohenian, that he underestimated Russian philosophy and relied exclusively on Cohen in his philosophy? Of course, such an assumption completely contradicts everything we know about Bakhtin. He was undoubtedly profoundly connected to Russian cultural 
soil. However, as a philosopher, he followed his original path, turning throughout his life to Hegel and Schelling, to Schopenhauer, Kierkegaard, Nietzsche, Rickert, Bergson, Husserl, Cassirer, and Scheler. All of Bakhtin's sources are unquestionable and can be seen in his texts and in his biography. However, Cohen was the central source, as confirmed by Bakhtin's testimonies throughout his life. During all these years, both early and late, Bakhtin never said he had departed from Cohen and changed his philosophical foundations. At the same time, it is clear that for Bakhtin, Cohen was only the starting point of his thinking, that he perceived Cohen critically, as a philosopher should perceive a philosopher.

As for Bakhtin's attitude to Russian thought, this is a significant topic to which a particular study should be devoted. For our work, it is sufficient to rely on Bocharov's formulation, the validity of which we see in Bakhtin's writings themselves:

"By inheriting its (Russian religious philosophy's) problematics, Bakhtin changed the language of philosophizing" [1. P. 487].

In other words, Bakhtin was a Russian Orthodox thinker by his interests, problems, cultural context, and a European philosopher by his method and the systematic nature of his thinking.

\section{The Responsible Person as a Subject of Systematic Philosophy}

Obviously, consideration of Bakhtin's philosophy should begin with his early works, in which he unequivocally states that he is going to establish a philosophical system. Bakhtin's first article, a short note entitled "Art and Answerability," published in 1919, is a kind of philosophical program. This almost homemade publication $^{7}$ is paramount for the researcher as a proclamation of the contours of Bakhtin's future philosophy. The development of the ideas of this note is contained in Bakhtin's works of 1919 - 1924, which all came out after the author's death.

To construct a philosophical system, it is first necessary to define its unified subject and a notable way of describing this subject. For philosophy, from the ancient Greeks up to Kant, the subject of universal philosophy was being, and the method was the study of the relation of thinking and being. Kant radically redefined the content of philosophy by making its main subject and method the critique of the subjective facility concerning the objects of cognition and the will. Although Kant was undoubtedly a pivotal reference point for Bakhtin, his philosophy was obviously aimed at overcoming the concept of subjectivity formulated in the three Kant's Critiques. Already in his essay "Art and Answerability," Bakhtin shows that "the three domains of human culture-science, art, and life" [4. P. 1] do not form unity and integrity by themselves. Bakhtin introduces the notion of responsibility as a unifying principle — In Bakhtin's English translations - answerability. "The

\footnotetext{
${ }^{7}$ The article was published in the Nevel's almanac "Day of Art" for September 13, 1919 but was found among M.M. Bakhtin's papers after his death [3. P. 347].
} 
individual must become answerable through and through" [4. P. 2]. As Bakhtin's commentators admit, this note is imbued with the spirit of Neo-Kantianism [3. P. 350, 416; 8. P. 224; 9. P. 15-33; 10. P. 75] $]^{8}$. Already in Ethics of Pure Will, Cohen states that in formulating the question of moral self-consciousness in ethics, "self-responsibility emerges as a real problem around which all questions revolve" [12. P. 350]. In Religion of Reason, Cohen is even more explicit about the primacy of responsibility in forming the autonomy of the human Self as a person and realizing an individual as universality [13. P. 187, 229] $]^{9}$.

Thus, Bakhtin's transformation of responsibility into a shaping factor of the philosophical system continues in this respect H. Cohen's efforts. However, in his note, Bakhtin only set the problem, the solution of which he probably planned to engage in the work Subject of Morality and Subject of Law. It is very probable that his philosophical texts Toward a Philosophy of the Act and Author and Hero in Aesthetic Activity, published after Bakhtin's death, represent drafts written while working on this book [3. P. 671]. The book's title attests to the fact that Bakhtin proposed a revision of the very notion of subjectivity. Bakhtin enumerates types of subjects:

In different areas of culture, we meet different types of the subject: the aesthetic hero, the historical hero, the cultural hero, the subject of law, the subject of morality [3. P. 164 $]^{10}$.

In this fragment, we notice that the relation between the author and the hero, often regarded as Bakhtin's most vital discovery [8. P. 96], is associated with his quest for an alternative to the Kantian notion of subjectivity. As mentioned earlier, H. Cohen was also involved in reinterpreting the concept of subjectivity into the concept of personality. Plainly moving in the same direction, Bakhtin made a comprehensive study of the responsible, creative personality the main topic of his searches.

At the very beginning of Toward a Philosophy of the Act, Bakhtin reformulates the problem posed in Art and Answerability as a "fundamental split between the content or sense of a given act/activity and the historical actuality of its being" [5. P. 2]. It is clear that these two sides of the act/activity, namely, content and eventfulness (historical reality), "a two-faced Janus," are the same two sides of a person, the artistic-cognitive and the vital, of which Art and Answerability was concerned. Their union is the task posed by Bakhtin. However, now, it is formulated differently. We are no longer talking about the life of a person but the "event of being." What makes it actual and integral? Bakhtin gives the same answer: "An act must acquire a single unitary plane to be able to reflect itself in both directions in its sense or meaning and in its being; it must acquire the unity of two-sided

\footnotetext{
${ }^{8}$ On Hermann Cohen's place in the philosophy of dialogue and on the continuity of Bakhtin's thinking in relation to Cohen, ref. [11].

${ }^{9}$ As A. Poma highlights, the transition from the question of individual responsibility to the issue of co-humanity is the inner core of the reversal of Cohen's system [14. P. 220-221].

${ }^{10}$ This fragment is not in the English translation, so it is quoted from the Russian original text.
} 
answerability — both for its content (special answerability) and for its Being (moral answerability)." [5. P. 2-3]. The two-sided answerability of the event of being is a new formulation of the relation between the object (content) and the subject (being itself). Yet, without the dualism inherent in Kantian philosophy — both sides are realized in the unified act of being event. However, such a formulation is insufficient for Bakhtin. Already in the first phrases of the surviving fragment Toward a Philosophy of the Act, Bakhtin characterizes in a negative form the problem he explores in his work.

"Aesthetic intuition is unable to apprehend the actual event-ness of the onceoccurrent event, for its images or configurations are objectified, that is, with respect to their content, they are placed outside actual once-occurrent becoming - they do not partake in it" [5. P. 1].

In this way emerges the formulation of the diagnosis of illness - nonpartaking. This characteristic acts as a negative formulation of Bakhtin's central philosophical attitude. In its positive formulation - partaking or participation soon appears on the pages of the treatise as well. He is speaking about "the actual historicity of Being-as-event" [5. P. 10], describing it as follows: "But in this case we have to do with an instance of participative thinking (which seeks to overcome its own givenness for the sake of what-is-to-be-attained)" [5. P. 11]. The concept of "answerable act" introduced at the beginning of the study now leads us to the concept of "participative thinking," which becomes the main subject of the study. This formulation testifies to the connection of participative thinking, with the answerable act with the logic of Cohen, for which the relation of this "givenness" (Gegeben) and "what-is-to-be-attained" (Aufgabe) is a central theme. The latter is used in Cohen's concept of correlation (Korrelation). Although Bakhtin constructs his philosophical language, the connection of partaking with correlation is undeniable. The notion of correlation, which was necessary for Cohen to overcome the dualism inherent in Kantian philosophy and the paradoxical nature of the concept of the thing-in-itself, ${ }^{11}$ leads to a change of reference points in philosophy, a change which Ernst Cassirer, Cohen's closest disciple, and like-minded person, called the transition from substance to function [15]. Let us consider how this notion works in the four parts of Cohen's philosophical system ${ }^{12}$. In the theory of cognition, correlation is necessary to investigate the correspondence of the subject and the thing in itself [16. P. 145]. Cohen understood correlation as the relation of thinking and the differential of the subject, or as the process of relating the finite and the infinite [16. P. 199-200]. Rosenzweig, as we know, redefines the concept of correlation with his notion of a path (Bahn). Paths unfold in the present tense, on which interpersonal relations and language operate [17. P. 119]. Suppose the

\footnotetext{
${ }^{11}$ On the perception of the Cohenian concept of correlation in the 1910s in Russia, ref. the comments of L. Gogotishvili [3. P. 624-625].

12 As A. Poma shows, the concept of correlation not only permeates all the elements of Cohen's system, but also binds them into a coherent whole [14. P. 61-86].
} 
procedural and correlative nature of cognition is the most crucial point in Cohen's logic of origins [16. P. 149-150], then in ethics, the procedural and correlative nature shifts to the subject itself. Cohen discovers that within subjectivity, there is a process of relating to the other. The human being is henceforth to be understood not as an individual but as an personality in correlation with the other. This I-Thou relationship that Cohen proclaims in his ethics is a relationship of responsibility [12. P. 197-202]. Based on his ideas, Cohen develops a fundamental philosophy of law, which, unlike Hegel's, is based on the dynamics of interpersonal relations. In his later works, Cohen extends this concept to aesthetics. Although the concept of responsibility is remarkable in both ethics and religion, in ethics, responsibility is realized in the concept of law, in religion in the concept of morality.

Thus, the notion of "partaking" continues the line of development of Cohen's philosophy. However, a question arises. Why does Bakhtin not explicitly refer to "partaking" as a "correlation" in Toward a Philosophy of the Act? The answer is in Author and Hero in Aesthetic Activity. Here Bakhtin provides an entirely Cohenian definition:

The correlation of the image-categories of I and the other is the form in which an actual human being is concretely experienced; this form of the I (the form in which I experience myself as the one-and-only me) is radically different from the form of the other (in which I experience all other human beings without exception). [4. P. 37-38].

To avoid misunderstandings, Bakhtin adds just below:

The point here is not the epistemological subject-object correlation, the point is the living correlation of me - the one-and-only subjectum, and the rest of the world as an object not only of my cognition and my outer senses, but also of my volition and feeling. [4. P. 38].

In other words, Bakhtin introduces the notion of partaking central to his philosophy. He draws on the Cohenian notion of correlation in all its realizations logical, aesthetic, ethical, and religious. As we have noted, a similar situation is observed in Rosenzweig. The notion of "partaking" is more suited to Bakhtin's cultural and linguistic context and more reflective of his main philosophical task the study of the individual participating in interpersonal relations. Thus, Bakhtin calls a participative (or partaking) responsible being of an event the subject of his philosophy. The discovery of the subject is the first step in constructing a philosophical system, but only the first step so far. What is needed to implement the other steps?

\section{How to Elaborate a Philosophical System}

Not all our contemporaries can comprehend the systematicity of dialogic philosophers like Rosenzweig and Bakhtin. For Rosenzweig, the systematicity of philosophy is expressed in the openness of the human personality, which is expressed in the concept of the Gestalt [17. P. 441]. For Bakhtin, systematicity also 
implies a combination of wholeness and openness and is expressed in the idea of the "architectonics of responsible action." The term architectonics, as a declaration of the systemic character of philosophy, was developed by Kant. Let us recall the essential provisions of Critique of Pure Reason (A832/B860): "By an architectonic, I understand the Art of Systems" [18. P. 691]. Further: "I understand by a system, however, the unity of the manifold cognitions under one idea" [18. P. 691]. In the introduction to Critique of Practical Reason, Kant speaks again about architectonics as a way "to grasp correctly the idea of the whole" [19. P. 8]. Let us note that Kant speaks of the system in two mutually complementary senses - as a philosophical system and as the unity of the subject matter of the philosophical system, i.e., reason. Continuing this line of thought, Cohen considers the unity of reason to be the basis of the systemic character of philosophy. For him, this unity is not a given, but something to be achieved, in other words, it is open. This turns philosophy into a "system of philosophical problems" [16. P. IX], which is realized in relation to the one and only God.

As we have seen in Bakhtin's early texts, he is engaged in the formation of his own system of philosophy, which the further he goes, the more he departs from its sources (Kant and Cohen) and acquires the traits of originality. The subject of Bakhtin's philosophical quest is not the rational subject of New-European philosophy, but the moral person realized and "incorporated into the unitary and onceoccurrent event of Being through the mediation of an answerable consciousness in an actual deed" [3. P. 12-13]. Therefore, the subject of Bakhtin's philosophical system should not be the architectonics of pure reason, as in Kant's case, but the architectonics of the "responsible deed," the "participatory event of being," etc. Bakhtin himself repeatedly talks about this. For instance:

"It is this concrete architectonic of the actual world of the performed act that moral philosophy has to describe, that is, not the abstract scheme but the concrete plan or design of the world of a unitary and once-occurrent act or deed" [5. P. 54].

What abstract schema are we talking about here? Kant, in his first Critique, regards the architectonics of pure reason as a schematism of ideas. Cohen does not like to use the term "architectonics" at all. Apparently, in this fragment by Bakhtin, we encounter a critique of Kantian, not Cohenian, philosophy. In his philosophy, Bakhtin replaces the theoreticism of the "abstract scheme," i.e., the architectonics of the mind, with a concrete plan for the world of a single and singular act.

The systematicity of Bakhtin's philosophy is carried out not in the unity of reason, as Kant had, but in "the actual architectonic of the actually experienced world" [5. P. 58]. In other words, Bakhtin's philosophy aims at investigating not the system of the world as a subject of reason (it was engaged in this from Descartes to Kant), but at investigating the system of the world as a subject of a responsible deed.

"The highest architectonic principle of the actual world of the performed act or deed is the concrete and architectonically valid or operative contraposition of I and the other" [5. P. 74]. <..> "This architectonic is something-given as 
well as something-to-be-accomplished, for it is the architectonic of an event. It is not given as a finished and rigidified architectonic, into which I am placed passively. It is the yet-to-be-realized plane of my orientation in Being-as-event or an architectonic that is incessantly and actively realized through my answerable deed" [5. P. 75].

These statements, imbued with the spirit of Neo-Kantianism, constitute Bakhtin's new system of philosophy. In order to better understand its essence, it is helpful to establish the affinity and distinction with its Neo-Kantian statements ${ }^{13}$. Among the studies on this subject, many prospects have been expressed, from perceiving Bakhtin as an epigone of Neo-Kantianism to denying his connection with Neo-Kantianism [21]. The historical studies of the Nevel and Vitebsk periods of the philosopher's work have prepared a sure basis for the solution of this problem. Let us especially mention the works of N.I. Nikolaev, one of which is directly related to our theme. Relying on archival materials, he confirms the assumption of the importance of Neo-Kantianism in the work of Bakhtin and his associates of this period:

the activities of the Nevel School until at least the mid-1920s took place within the framework of the problems of H. Cohen's philosophy [22. P. 224].

At the same time, Nikolaev notes the creative, active nature of the philosophical discussions of Bakhtin, Kagan, Pumpyanskiy, and their associates:

Just as H. Cohen revisited Kant, reinterpreting and excluding a number of his notions, the Nevelian Cohenians revisited Cohen" [22. P. 226].

Calling Bakhtin a "Cohenian", Nikolaev nevertheless does not engage in a detailed discussion of Cohen, nor does he analyze the specifics of his influence on Bakhtin. However, philosophical research on Bakhtin began as early as the $1980 \mathrm{~s}^{14}$. In this context, let us note the works of L.A. Gogotishvili [3], the studies of V.L. Makhlin, and the philosophical reception of Bakhtin by V.S. Bibler [9]. Makhlin explores Bakhtin's philosophical problems in the most detailed and elaborate way ${ }^{15}$. He admits the connection between Bakhtin and Cohen, yet Cohen himself is presented as a model of obsolete $19^{\text {th }}$-century theoretical philosophy. In his article "Systematic Concept" (Notes on the History of the Nevel School) [10], Makhlin directly investigates the systematic character of Bakhtin's philosophy.

\footnotetext{
${ }^{13}$ In one of the first summary monographs on Bakhtin by Clark and Holquist, it was already stated that Bakhtin drew on the Neo-Kantianism of the Marburg School and, above all, the philosophical system of Hermann Cohen in the development of his doctrine. [20].

${ }^{14}$ Works concerning Bakhtin's philosophy, both in Russia and abroad, are innumerable. They formulate a wide variety of versions of the belonging of this philosophy from existentialism (Bonetskaya) [23], to orthodox theology (Kozhinov) [24].

${ }^{15}$ We note in particular V.L. Makhlin's attempt to consider Bakhtin's philosophy historically and systematically as part of the intellectual processes of the 20th century. Thus, in his 1997 monograph [25], he compares Bakhtin's philosophy with the philosophy of Rosenzweig, Buber and Ebner. Other works trace the connection of Bakhtin's thinking to other philosophers of the early 20th century.
} 
The research subject is the last of Bakhtin's early works, The Problem of Content, Material, and Form in Verbal Art [4. P. 257-325]. Although the article is devoted to aesthetics, it raises questions of a general philosophical nature, including the problematics of the system:

"without a systematic concept of the aesthetic in its distinctness from the cognitive and the ethical as well as in its interconnectedness within the unity of culture, it is impossible even to isolate the object to be studied by poetics" [4. P. 259].

As an illustration of the connection between Bakhtin's and Cohen's ideas, Makhlin quotes the introduction to Aesthetic of Pure Feeling:

Just as philosophy in general can be essentially and historically justified only as a system, so every problem area of philosophy has its final foundation, its true unity, only in a system. This is why philosophical aesthetics is defined as systematic aesthetics [26. P. XI].

Note that for both philosophers, the systemic character of aesthetics signifies the expression in the aesthetic of the general philosophical content of the unity of the subject. As Makhlin notes, Bakhtin, in his understanding of the subject and the system, attempts to overcome the theorizing of New European philosophy of subjectivity ${ }^{16}$. Further on, Makhlin's article I mentioned contains a valuable formulation of the understanding of the system in Bakhtin's philosophy:

Bakhtin "postulates a new type of system $<\ldots>$ - a system or "whole," whose elements enter the system $<\ldots>$ as elements of the partake free, partake outside to its own system. In this connection, the conception of the ontology of partaking or, otherwise, the philosophy of partake freedom becomes clearer [10. P. 81].

The extent to which Bakhtin's understanding of the system relates to the philosophy of Cohen can be understood by comparing it with similar attempts by Rosenzweig. As the American scholar Benjamin Pollock shows, Rosenzweig's philosophy does not oppose the systematicity of German classical idealism but instead tries to formulate a new type of systematic philosophy that goes beyond this idealism. As Pollock points out, Rosenzweig drew on Cohen's systematic philosophy [27. P. 65. Note 121]. Rosenzweig regarded Cohen as a pioneer of a new understanding of the system. In the introduction to the academic edition of Hermann Cohen's Jewish works (1924), Rosenzweig writes:

Cohen was "the only one among his peers in these decades, to go the way to System. He does so in conscious rejection and unconscious following of the

\footnotetext{
${ }^{16}$ The question of what kind of theorizing Bakhtin is overcoming requires a thorough investigation, which cannot fit into the framework of this article. In particular, it seems to us that the assumption that Bakhtin's critique of theorizing is directed against Cohen is not well founded. Rather, Bakhtin, as well as philosophers of dialogue in Germany, are each trying in their own way to solve the same problem as Cohen.
} 
great thinkers, who had, at the beginning of the century, melded together Kant's thinking and Goethe's life into the cultural power of German Idealism" [28. P. 181] $]^{17}$.

In other words, Rosenzweig thought that Cohen's understanding of the system contains Kantian and Goethean details. To clarify Rosenzweig's thought, Pollock cites a fragment from his famous letter to Ehrenberg on December 1, 1917:

System is not architecture, where the stones assemble the edifice and exist for the sake of the edifice but rather system means that every individual has the drive and the will to relate to all other individuals; the "whole" lies beyond its conscious circle of vision; <.. > if the "whole" is no longer the content of the system, then it must be the form of the system; <.. $>$ The philosopher is the form of philosophy [29. N 460. P. 484].

Thus, both Rosenzweig in 1917-1919 and Bakhtin in 1919-1924 were engaged in building a system in their ways, based on the individual perception of Cohen's philosophical system. For all three thinkers, the system lies in the ability of the individual to realize reality as a whole in addressing another person. However, the explication of this idea is different for each of them. For Cohen, it lies in his four-part system of philosophy, which is crowned by the Religion of Reason, which is in correlation with God; for Rosenzweig, in the dynamics of the relationship between God, Man and the World, which are both closed and open; for Bakhtin, in his project of moral philosophy of partake being, fragments of which were written in 1919-1924.

\section{Philosophy of Moral Reality. Summing up}

So, the subject and method of philosophy have been defined. The nature of the system, too. Why this doctrine is called "moral philosophy" [3. P. 416-417]. In one of his articles, Nikolaev says that discovering "moral reality" was Bakhtin's major achievement [8. P. 96]. The moral reality was much talked about during walks. Even the lake near Nevel was called "the lake of moral reality." However, this term is not so essential in Bakhtin's philosophical texts, although he uses it to describe "the reality of the act, the moral reality of the one and only event of being" [3. P. 245]. If we consider morality as a characteristic of a philosophical system, then we must understand Bakhtin's contrast between "Subject of morality" and "Subject of law."

Kant explores the ethical foundations of law in Critique of Practical Reason and the Groundwork of the Metaphysics of Morals. Cohen follows Kant's footsteps but develops his teachings substantially [30]. Already in his Ethics, Cohen views law in the context of $I$ and Thou interpersonal relationship. Meanwhile, in his philosophy of religion, he shows a fundamental difference between ethics and morality. The ethical subject, according to Cohen, is realized in the context of a

${ }^{17}$ Quoted in translation by B. Pollock [27. P. 65. Note 121]. 
relationship with another person based on mutual responsibility and thus has a legal character. However, the Religion of Reason formulates a new interpersonal relationship based not on legal, ethical obligations but on love. Thus, it turns out that the morality of religion, although based on ethics, goes beyond $\mathrm{it}^{18}$. The dominant difference between the religious-moral and the ethical-legal position in Cohen's teachings lies in the understanding of man. In ethics, a human being is regarded as a representative of humanity. The relations between people are built on a legal basis [12. P. 234-236], another person is defined as a Partner or Next man (Nebenmensch) [12. P. 198]. In religion, a man acts as the exponent of humanity's wholeness. The other man is regarded as Neighbor or Fellowman (Mitmensch) [13. P. 113-115]. Thus, according to Cohen, religion, in comparison with ethics, significantly expands the concept of morality ${ }^{19}$.

To illustrate Cohen's point, here is an excerpt from Religion of Reason:

Humanity is the subject of universal morality. According to ethics, the individual man is able to fulfill the demands of morality only in the image of humanity and, therefore, only within ethics' own competence, namely, in the autonomous law of its reason. The latter is not responsible for anything that happens beyond its borders and basically, therefore, is not interested in the outward success or failure of moral duty. Yet here, too, religion objects to this fiction of indifference. It must not be a matter of indifference whether my morality and all men's morality remains dutiful striving only, sufficient in itself; rather, I have to take an interest in the question of whether the ideal has life and actuality. Even though this identity can only be achieved in the approximation to the ideal, the inexorable goal of the approximation is the permeation of actuality with the ideal [13. P. 20-21].

This fragment could be seen as a preface to Bakhtin's philosophy. It shows quite clearly the distinction between ethics and religious morality, according to Cohen. It is very likely that for Bakhtin, this distinction served as a prerequisite for the distinction between the subject of morality and the subject of law. Cohen speaks of unindifference and then speaks of religious love for one's neighbor. Bakhtin speaks of non-partaking. The basis of their reasoning is undoubtedly familiar. At the same time, it is evident that Bakhtin understands religious morality differently than Cohen did. He intended to devote considerable attention to this problem. At the end of the Introduction to the Toward a Philosophy of the Act, there is an outline of the entire philosophical system. First, Bakhtin defines its content:

"The world in which a performed act orients itself on the basis of its onceoccurrent participation in Being - that is the specific subject of moral philosophy." [5. P. 53].

\footnotetext{
18 The comparison of morality and law is descriptive not only of Cohen, but also of the entire Marburg School. In particular, Natorp's concept of ethical socialism is based on it [31].

${ }^{19}$ Worth noting that God is a necessary element both ethically and morally. But in the ethics, he acts as a guarantor, and in the moral, as a participant [13. P. 24].
} 
Next are the sections of the system, which probably coincide with the plan of the treatise:

"The first part of our inquiry will be devoted to an examination of these fundamental moments in the architectonic of the actual world of the performed act or deed - the world actually experienced, and not the merely thinkable world. The second part will be devoted to aesthetic activity as an actually performed act or deed, both from within its product and from the standpoint of the author as answer-able participant, and [2 illegible words] to the ethics of artistic creation. The third part will be devoted to the ethics of politics, and the fourth and final part to religion." [5. P. 54].

What we have before us is a plan which coincides entirely with the elements of Cohen's philosophical system ${ }^{20}$. But the system itself, of course, was supposed to be different. Let us consider more closely the passage quoted by Cohen, as he notes that the morality of the individual coincides with the morality of humankind "only in the approximation." What is this approximation? The German word Annäherung means convergence or approximation, the same root of the word "near" (Nächste). Cohen explains this word in Religion of Reason. [13. P. 313] he uses the Hebrew התקרבות "proximity," which is very similar in meaning to partaking or touch. Cohen emphasizes that we are talking about internal, not external, proximity. Using the word Nähe, he says that nearness to God (Nähe Gottes) is different from self-nearing to God (Nähe zu Gott) [13. P. 191] $]^{21}$.

In Matvei Kagan's notes to Religion of Reason, which was very probably familiar to Bakhtin, there is the following explanation:

we meet in the Psalms the concept of "nearness" to God. It is not unity with God, but intimacy (התקרבות), approximation, which has the meaning of selfnearness as an act. The approach is not out of some foreign impulse, but out of an inner love. The love of God for man, man for God, man for man is harmonious in monotheism" [32. P. 61-62].

Thus, proximity to God, as expressed in human action, is the very participation or belonging we are discussing. It is also love. Rosenzweig in The Star of Redemption explains that the concept of loving one's neighbor as the realization of love for God is a common property of Judaism and Christianity [17. P. 221]. How this concept is expressed in Cohen's religious philosophy is well known. How it might be expressed in Bakhtin's religious doctrine, we can only guess. At least in the text of Toward a Philosophy of the Act, we find a striking statement on this subject:

"Whence it does not follow at all, of course, that the contraposition of I and the other has never been expressed and stated-this is, after all, the sense of all

\footnotetext{
${ }^{20}$ Rosenzweig, in his article The New Thinking, calls the same sections a holy custom in the construction of a philosophical system [33. P. 111].

${ }^{21}$ Considering in this fragment the difference between the two understandings of proximity, Cohen states: "Nacheiferung, nicht Nachahmung" (Emulation is not copying).
} 
Christian morality. <..> But this principle of morality has still not found an adequate scientific expression, nor has it been thought through essentially and fully" [5. P. 75].

At this point, various interpretations of the notions of "proximity" or "belonging" in the religious philosophy of the Jew Cohen and the Russian Orthodox Bakhtin are possible. In the extant part of the foundations of his "first philosophy," Bakhtin sets himself the task of expressing moral philosophy precisely in a scientific way. It is quite possible that in a later text, he planned to formulate an expression of morality from the perspective of the Christian religion.

Let us summarize our study. The connection of early Bakhtin's thinking with Cohen's philosophy can be considered proven both biographically, historically. and conceptually. This does not question the originality of Bakhtin's philosophy. On the contrary, it shows its connection with the fundamental foundations of the philosophy of the early $20^{\text {th }}$ century. At the same time, a study of Bakhtin's thinking can significantly enrich our understanding of Cohen's philosophy.

\section{References}

[1] Bocharov SG. Plots of Russian literature. Moscow: Yazyki russkoj kul'tury; 1999. (In Russian).

[2] Bakhtin MM, Duvakin VD. Conversations of V. Duvakin with M. Bakhtin. Moscow: Progress; 1996. (In Russian).

[3] Bakhtin MM. Collected Works. Vol. 1. Moscow: Yazyki slavyanskikh kultur; 2003. (In Russian).

[4] Bakhtin MM. Art and answerability: Early Philosophical Essays. Holquist M, Liapunov V, editors. Texas: University of Texas Press; 1990.

[5] Bakhtin MM. Toward a philosophy of the Act. Holquist M, Liapunov V, editors. Texas: University of Texas Press; 1999.

[6] Epelboin A. Conversation with Bakhtin on January 25, 1971. Judaica Petropolitana. 2021;(13). (In print). (In Russian).

[7] Kagan YuM. People not of our time. In: M. M. Bakhtin: pro et contra. Vol. I. St Petersburg: RHGA Publ.; 2001. P. 85-97. (In Russian)

[8] Nikolaev NI. M. M. Bakhtin in Nevel in the summer of 1919. In: Nevelskij sbornik. [Nevel's Collection]. St. Petersburg: Acropolis. 1996;(1):96-101. (In Russian).

[9] Bibler VS. Mikhail Mikhailovich Bakhtin or Poetics of Culture. Moscow: Progress, Gnosis; 1991. (In Russian).

[10] Makhlin VL. "Systematic concept" (Notes on the history of the Nevel school). Nevelskij sbornik. [Nevel's Collection]. 1996(1):75-88. (In Russian).

[11] Dvorkin I. The Place of Hermann Cohen's Ideas in the Philosophy of Dialogue. Kantian Journal. 2020;39(4):62-94.

[12] Cohen H. Ethik des reinen Willens. Berlin: Cassirer; 1904.

[13] Cohen H. Religion of Reason out of the Sources of Judaism. Kaplan S, translator. New York: F. Ungar; 1972.

[14] Poma A. Yearning for form and other essays on Hermann Cohen s thought. Dordrecht: Springer; 2006. 
[15] Cassirer E. Substance and function, and Einstein's theory of relativity. Chicago, London: The Open Court Publishing Company; 1923.

[16] Cohen H. Logik der reinen Erkenntnis. Berlin: Cassirer; 1902.

[17] Rosenzweig, F. The Star of Redemption. Galli BE, translator. Madison, WI: University of Wisconsin Press; 2005.

[18] Kant I. Critique of Pure Reason. Guyer P, Wood AW, translators and editors. Cambridge: Cambridge University Press; 1998.

[19] Kant I. Critique of Practical Reason. Gregor M, Reath A, translators and editors. Cambridge: Cambridge University Press; 2015.

[20] Clark K. and Holquist M. Mikhail Bakhtin. Cambridge: Harvard University Press; 1984.

[21] Belov VN. Perception of M.M. Bakhtin in the West: some general remarks. RUDN Journal of Philosophy. 2017;21(1):93-97. (In Russian).

[22] Nikolaev NI. Lectures and speeches of M. M. Bakhtin 1924-1925. in the notes of L.V. Pumpyatnsky. In: M.M. Bakhtin as a Philosopher. Moscow: Nauka; 1992. P. 221-252. (In Russian).

[23] Bonetskaya NK. Bakhtin through the eyes of a metaphysician. Moscow; St. Petersburg: Center for Humanitarian Initiatives; 2016. (In Russian).

[24] Kozhinov VV. The great creator of Russian culture of the XX century. In: The fate of Russia: yesterday, today, tomorrow. Moscow: Voenizdat; 1997. (In Russian).

[25] Makhlin VL. I and the Other: Towards the History of the Dialogical Principle in the Philosophy of the Twentieth Century. Moscow: Labirint; 1997. (In Russian).

[26] Cohen H. Ästhetik des reinen Gefühls. In 2 Bdn. Berlin: Cassirer; 1912.

[27] Pollock B. Franz Rosenzweig and the Systematic Task of Philosophy. New York, Cambridge University Press; 2009.

[28] Rosenzweig F. Der Mensch und sein Werk. Gesammelte Schriften. Bd. III. Zweistromland. Kleinere Schrift en zu Glauben und Denken. Mayer R, Mayer A, editors. Dordrecht: Martinus Nijhoff; 1984.

[29] Rosenzweig F. Der Mensch und sein Werk. Gesammelte Schriften. Bd. I. Briefe und Tagebücher. 1900-1918. Rosenzweig R, Rosenzweig-Scheinmann E, Casper B, editors. Hague: Martinus Nijhoff; 1979.

[30] Gibbs R. Jurisprudence is the Organon of Ethics: Kant and Cohen on Ethics, Law, and Religion. In: Hermann Cohen`s Critical idealism. Munk R, editor. Dordrecht: Springer; 2005. P. 193-230.

[31] Natorp P. Recht und Sittlichkeit. Ein Beitrag zur kategorialen Begründung der praktischen Philosophie. Kant-Studien. (18): 1-79.

[32] Kagan MI. On the Course of History. Moscow: Yazyki slavyanskikh kultur; 2004. (In Russian).

[33] Rosenzweig F. The New Thinking. In: Rosenzweig F. Philosophical and Theological Writings. Franks PW, Morgan ML, translators and editors. Indianapolis/Cambridge: Hackett Publishing; 2000. P. 109-139.

\section{About the author:}

Dvorkin Ilya - Director of the Educational Programs at International Center for University Teaching of Jewish Civilization, Hebrew University of Jerusalem, Jerusalem, Israel (e-mail: idvorkin@mail.ru). 


\title{
Бахтин и Коген: шаги к философской системе
}

\author{
Илья Дворкин $\bowtie$ \\ Еврейский университет в Иерусалиме, \\ Israel, 9190501, Jerusalem, Mt. Scopus \\ \idvorkin@mail.ru
}

\begin{abstract}
Аннотация. Хотя общеизвестно, что М.М. Бахтин считал себя в первую очередь философом, а не филологом, подавляющее большинство исследований его творчества носят литературоведческий характер. Задача настоящей статьи, опираясь на устные свидетельства самого Бахтина и на его философские тексты, написанные им в невельсковитебский период (1919-1924) восстановить характер его философских источников и содержание его философских идей этого времени. В качестве такой центральной идеи рассматривается концепция нравственной философии как философской системы, главным предметом которой является участное мышление и ответственный поступок как событие бытия. Одним из важнейших источников этих идей, вероятно, являлась философия неокантианства в лице учения Г. Когена. В статье приводится четыре примера преемственности Бахтина по отношению к марбургскому философу - идея ответственного поступка по отношению к другому человеку как истока собственного самосознания человека и целостности личности, идея коррелятивного отношения между человеком и его ближним как выражение небезразличного участного бытия, идея отличия нравственного отношения от этико-правового и идея философской системы, предметом которой является процесс межличностных отношений. При этом система состоит не только в целостности предмета, но и в его открытости. Выявление преемственности философских идей Бахтина по отношению к Когену позволяет значительно лучше понять сами эти идеи и оригинальность их разработки Бахтиным. Плодотворным оказывается также сравнение восприятия идей Когена у Бахтина и их рецепции у другого философа диалога Ф. Розенцвейга.

Ключевые слова: Бахтин, Коген, Розенцвейг, участное мышление, поступок, ответственность, корреляция, событие бытия, система, нравственность, этика, философия диалога
\end{abstract}

\section{История статьи:}

Статья поступила 14.05.2021

Статья принята к публикации 03.08.2021

Для цитирования: Dvorkin I. Bakhtin and Cohen: The First Stages in Building the Philosophical System // Вестник Российского университета дружбы народов. Серия: Философия. 2021. Т. 25. № 3. С. 436-456. DOI: 10.22363/2313-2302-2021-25-3-436-456

\section{Список литературы}

[1] Бочаров С.Г. Сюжеты русской литературы. М. : Языки русской культуры, 1999.

[2] Бахтин М.М., Дувакин В.Д. Беседы В.Д. Дувакина с М.М. Бахтиным / вступ. ст. С.Г. Бочарова и В.В. Радзишевского ; закл. ст. В.В. Кожинова. М. : Прогресс, 1996.

[3] Бахтин М.М. Собр. соч. М. : Языки славянских культур, 2003. Т. 1. 
[4] Bakhtin M.M. Art and answerability: early philosophical; edited by Michael Holquist and Vadim Liapunov; translated and notes by Vadim Liapunov; supplement translated by Kenneth Brostrom. Texas : University of Texas Press, 1990.

[5] Bakhtin M.M. Toward a philosophy of the Act. Translated and notes by Vadim Liapunov; edited by Vadim Liapunov and Michael Holquist. Texas : University of Texas Press, 1999.

[6] Epelboin A. Разговор с Бахтиным 25 января 1971 г. // Judaica Petropolitana. 2021. № 13. (В печати).

[7] Каган Ю.М. Люди не нашего времени // М.М. Бахтин: pro et contra. СПб. : РХГИ, 2001. T. I. C. $85-97$.

[8] Николаев Н.И. М.М. Бахтин в Невеле летом 1919 г. // Невельский сборник. СПб. : Акрополь, 1996. Вып. 1. С. 96-101.

[9] Библер В.С. Михаил Михайлович Бахтин или Поэтика культуры. М. : Прогресс, Гнозис, 1991.

[10] Махлин В.Л. «Систематическое понятие» (Заметки к истории Невельской школы) // Невельский сборник. Вып. 1. СПб. : Акрополь, 1996. С. 75-88.

[11] Дворкин И.С. Место идей Германа Когена в философии диалога // Кантовский сборник. 2020. Т. 39, № 4. С. 62-94.

[12] Cohen H. Ethik des reinen Willens. Berlin : Cassirer, 1904.

[13] Cohen H. Religion of Reason out of the Sources of Judaism. Translated, with an introduction, by S. Kaplan. New York : F. Ungar. 1972.

[14] Poma A. Yearning for form and other essays on Hermann Cohen s thought. Dordrecht : Springer, 2006.

[15] Cassirer E. Substance and function, and Einstein's theory of relativity. Chicago, London : The Open Court Publishing Company, 1923.

[16] Cohen H. Logik der reinen Erkenntnis. Berlin : Cassirer, 1902.

[17] Rosenzweig F. The Star of Redemption. Translated by B. E. Galli. Madison, WI : University of Wisconsin Press, 2005.

[18] Kant I. Critique of Pure Reason. Translated and edited by P. Guyer and A. W. Wood. Cambridge : Cambridge University Press, 1998.

[19] Kant I. Critique of Practical Reason. Translated and edited by M. Gregor and A. Reath. Cambridge : Cambridge University Press. 2015.

[20] Clark K., Holquist M. Mikhail Bakhtin. Cambridge : Harvard University Press, 1984.

[21] Белов В. Н. Восприятие М. М. Бахтина на Западе: несколько общих замечаний // Вестник Российского университета дружбы народов. Серия «Философия». 2017. T. 21. № 1. С. $93-97$.

[22] Николаев Н. И. Лекции и выступления М.М. Бахтина 1924-1925 гг. в записях Л.В. Пумпянского // М.М. Бахтин как философ. М. : Наука, 1992. С. 221-252.

[23] Бонецкая H. K. Бахтин глазами метафизика. М., СПб. : Центр гуманитарных инициатив, 2016.

[24] Кожинов В.В. Великий творец русской культуры XX века // Судьба России: вчера, сегодня, завтра. М. : Воениздат, 1997.

[25] Махлин B.Л. Я и Другой: К истории диалогического принципа в философии ХХ века. М.: Лабиринт, 1997.

[26] Cohen H. Ästhetik des reinen Gefühls: in 2 Bdn. Berlin: Cassirer, 1912.

[27] Pollock B. Franz Rosenzweig and the Systematic Task of Philosophy. New York, Cambridge University Press, 2009.

[28] Rosenzweig F. Der Mensch und sein Werk. Gesammelte Schriften. III. Zweistromland. Kleinere Schrift en zu Glauben und Denken. Edited by Reinhold and Annemarie Mayer. Dordrecht: Martinus Nijhoff, 1984. 
[29] Rosenzweig F. Der Mensch und sein Werk. Gesammelte Schriften. I. Briefe und Tagebücher. 1 Band 1900-1918. Edited by Rachel Rosenzweig and Edith RosenzweigScheinmann with the cooperation of Bernhard Casper. Hague: Martinus Nijhoff, 1979.

[30] Gibbs R. Jurisprudence is the Organon of Ethics: Kant and Cohen on Ethics, Law, and Religion // Hermann Cohen`s Critical idealism. Ed. By R. Munk. Dordrecht: Springer, 2005. P. 193-230.

[31] Natorp P. Recht und Sittlichkeit. Ein Beitrag zur kategorialen Begründung der praktischen Philosophie // Kant-Studien. 18. P. 1-79.

[32] Каган М.И. О ходе истории. М.: Языки славянской культуры, 2004.

[33] Rosenzweig F. The New Thinking / Philosophical and Theological Writings. Translated and Edited, with Notes and Commentary, by Paul W. Franks and Michael L. Morgan. Indianapolis, 2000. P. 109-139.

\section{Сведения об авторе:}

Дворкин Илья - руководитель образовательных программ Международного центра университетского преподавания еврейской цивилизации, Еврейский университет в Иерусалиме, Иерусалим, Израиль (e-mail: idvorkin@mail.ru). 